\title{
Graduate Employability: Perception of Graduate Students on Soft Skills Towards Employability in Bangladesh
}

\author{
Md Atiqur Rahman Sarker ${ }^{1}$ \\ Junaidah Binti Hashim ${ }^{2}$ \\ Ahasanul Haque ${ }^{3 *}$ \\ Nurita Binti Juhdi ${ }^{4}$ \\ Department of Business Administration ${ }^{1,2,3,4}$ \\ International Islamic University Malaysia (IIUM), Malaysia ${ }^{1,2,3,4}$
}

\begin{abstract}
Career opportunity for newly graduated candidates in Bangladesh is challenging at present due to high job demand, skill gap and lack of practical experiences. Thus, this study emphasises on student's perception regarding the importance of soft skills acquisition towards their employability. This study has collected survey responses from 326 final year students from ten different private and public universities in Bangladesh. Structural Equational Modelling (SEM) technique has been used to investigate the relationship between different soft skills and employability through analysis of Exploratory Factor Analysis (EFA) and Confirmatory Factor Analysis (CFA). Significant relationships among communication, critical thinking, teamwork and employability have been found in this study. This study is limited to the soft skills acquisition and graduates' employability. Further study can be conducted between the relationship of different soft skills and Human Resource Management (HRM) practices. This study provides a significant contribution to the literature by exploring the key soft skills that have relationship with employability. It also promotes the acquisition and practice of soft skills in finding jobs for newly graduated job candidates.
\end{abstract}

Keywords: Career, Employability, Skill Gap, Soft Skills, Students, Bangladesh

*Corresponding Author: Ahasanul Haque, Email: ahasanul@iium.edu.my

DOI: https://doi.org/10.37227/jibm-2021-03-87/

\section{Introduction}

Employers assume that employability for newly graduated candidates is their readiness to work with certain set of skills, awareness, attributes and commercial knowledge which assist them to be more productive in the organization immediately after getting a job (Majid et al., 2012; Mason et al., 2006). A maximum number of employers are demanding an assortment of different skills like technical competencies, interpersonal, critical thinking, leadership and managerial capabilities reinforced by the educational system from their employees (Patacsil \& Tablatin, 2017). Currently, employers are giving more emphasize on higher level skills of employability and adjustability with industrial prompt changes along with technical expertise to locate right employees in right place (Sattar et al., 2012; Khata et al., 2013; Fong 
et al., 2014). In this regard, the soft skills acquisition among students has become essential at present time. Soft skills have been a subject of life-long learning that have application in every aspects of life. Personal development of individual gets enabled and enhanced through the development of soft skills (Gibb, 2014). Soft skills include personal accountability, strong work ethics, positive attitudes, self-motivation, the degree of collaboration, interpersonal skill, conflict resolution, negotiation skill, people's adaptability and flexibility, the clarity of communication, creative thinking, and the ability of coaching and mentoring etc. (Taylor, 2016; Zaman et al., 2018). Learning success of soft skills influences individual behaviour both in social and professional life (Gibb, 2014; Zaman et al., 2018). Soft skills practice has impact in developing social skills as well as professional competency. Employers now a days demand their employees practicing soft skills, which have positive impact on serving customers with service quality and satisfaction (Patacsil et al., 2017). Some researches reveal that in many situations at work, soft skills are even more importance than technical skills. Pritchard (2013) has mentioned that 75\% of employers are looking for employees with soft skills. Patacsil \& Tablatin (2017) have studied on IT professional and found out that soft skills practice is needed for business growth and sustainability. Interpersonal communication, critical thinking and problem solving ability are crucial to develop for an employee to become skilled professional (Naim, 2017). Beyond the technical knowledge on occupation, employers also look for the workforce to be ethical, agreeable, leader and team spirited (Johnson, 2016; Majid et al., 2012). Therefore, the assessment of soft skills is widely practiced while hiring new employees.

Job market for fresh graduates is getting competitive in Bangladesh at present. Developing employability through higher education can improve employment prospect and also achieve personal learning goals. However, there is a skill gap among newly graduated students who have academic knowledge only, but have lack of practical experience which can be overcome through acquisition of soft skills (Roos et al., 2016). It is essential to acquire soft skills through training, especially self-training, attending language classes, presentation skills development session and socializing with others (Kechagias, 2011). It is also found that the practice of soft skills at work is comparatively low in Bangladesh and very few initiatives have been taken by the employers to develop these skills (Hossan et al., 2012; Zaman et al., 2018). Therefore, this study is primarily focusing on the perception of students about the importance of soft skills acquisition and its relationship towards getting job at the beginning of their career. This study identifies the most commonly perceived soft skills needed for employability of students in Bangladesh analysed through Exploratory Factor Analysis (EFA). Then, the relationships among soft skills (extracted through EFA) practices and graduates' employability have been tested by using Structural Equation Modelling (SEM) where Confirmatory Factor Analysis (CFA) has been done at the beginning.

This study provides a significant contribution to the literature by exploring the key soft skills that have relationship with employability. It also promotes the acquisition and practice of soft skills in finding jobs for newly graduated candidates. Since very few studies have been conducted on soft skills practice in Bangladesh, this study will draw the attention of academic institutes to emphasise more on soft skills development of their students and include these into curriculums.

\section{Literature Review}

Students from different academic background are striving to get a job in their relevant areas. Many of students may not get a job instantly after completing their studies for their lacking in some set of skills. In a study of World Bank in India, the findings indicated that graduates 
have the prevalent skill gap between complex intellectual skills (rational, mathematical and problem solving capability) and simple intellectual skills such as communication and critical thinking (Andreas \& Hiroshi, 2011). Due to global competition in the labor market, graduates are facing difficulties to get a job and falling in aggressive competition. To be competent and forceful in the job market, students should attain a set of soft skills for increasing the employability skill (Azami et al., 2009). Employers always seek a certain set of employment qualities like problem solving, strong work ethic and decision making skills while taking candidates' job interview (Kechagias, 2011). However, employers face a challenge to recognize the potential employee who has the competency in both technical and soft skills (Shafie \& Nayan, 2010). Graduates must understand the recruiters' demanding issues to prepare themselves as proficient candidates for getting employment in the desired working place. This study is focusing on important soft skills needed for getting job.

Soft skills refer both personal qualities and interpersonal skills that make individual emotionally intelligent and engaged with other in order to bring desired state of affairs (Zaman at al., 2018). Soft skills are the human skills such as assertiveness, behavioural competency, creativity, engagement, leadership, work ethics, self-control and openness (Alam et al., 2010; Rao, 2017; Szilárd et al., 2018). It is also known as personal skills that include communication, team work, creativity and problem solving. According to Yeardley (2017), soft skills mean delegation, networking, time management, team building capacity and awareness of individual. Therefore, soft skills include personal accountability, strong work ethics, positive attitudes, self-motivation, the degree of collaboration, interpersonal skill, conflict resolution, negotiation skill, people's adaptability and flexibility, the clarity of communication, creative thinking, and the ability of coaching and mentoring. Tang (2018) stated that soft skills are personal traits that enhance interaction, job performance and career growth. Rao (2015) mentioned that soft skills are essential for both career growth and social competence. Someone possess soft skill has more social skills for interaction and networking that enables the person to be accomplished more. Unlike hard skills (technical skills) which are learned by training, soft skills are more related with emotions and insights that are very difficult to measure and evaluate (Wesley et al., 2017). Soft skills have become significant both in personal and profession life. Possessing soft skills help individual to connect psychologically with others. Therefore, practice of soft skill helps individual and the organization to understand the needs of others, and directs them to act accordingly for mutual benefits.

This study is considering Social Exchange Theory (SET) for understanding students' perception on soft skills, which is developed for obtaining job at the beginning of the career. SET refers human behaviour based on the notion of mutual relationship between two parties (Emerson (1976). Social interaction as well as communication in organization are needed for working in a team (Nazir et al., 2018; Waskito et al., 2020). This is basically explained in SET. Cross \& Dundon (2019) have mentioned the importance of SET for employment relations and Human Resource Management (HRM). It is assumed that critical thinking skills, communication ability and adaptability in teamwork can make employee more compatible for getting a job. Thus, these skills are emphasized more by the graduates for their employability, which is their ultimate goal as return. 


\section{Hypothesis Development}

Soft skills development among students are essential for finding job. Employers mostly look for few specific soft skills during hiring new employees which include creativity, integrity, leadership, critical thinking, strong work ethics, positive attitude, communication, time management, teamwork, problem solving, self-confidence etc. (Patacsil \& Tablatin, 2017). Before hiring new employees, recruiters in general like to see a fine blend of soft skills and competencies among the job candidates in addition to discipline-based knowledge and skills. However, employers often find soft skills deficiency among the job applicants (Johnson, 2016; Kechagias, 2011; Roos et al., 2016). Therefore, soft skills have become one of the needed criteria while hiring employees. Since soft skills help one to get and keep a job as well as successfully influence and lead others at work (Rao, 2017), these have become crucial to find out the most commonly perceived soft skills needed for student's employability in Bangladesh. For this study, only three most common soft skills are considered to investigate the perceptions of students. These are communication, critical thinking and teamwork.

Communication is the daily activity that everyone does at work. Employees communicate with managers and clients on a regular basis, and effective communication is essential at every level. Employers believe that communication is mostly needed soft skills to develop since employees often need to involve with jobs that require different level of leadership and decision making activities (Majid et al., 2012; Patacsil \& Tablatin, 2017). Through communication employees can exchange their ideas and knowledge with the management, and it also helps them to deal with customers. It is perceived that communication skills help employee to negotiate and network professionally (Rao, 2017). Good communication develops the relationship between employee and employer. It reduces misunderstanding and opens the floor of cooperation and coordination for mutual benefits. Therefore, communication is one of the most demanding skills that employers always seek while hiring employees. Based on this discussion the following hypothesis is developed to examine the relationship between communication skills and employability.

$\boldsymbol{H}_{1}$ : There is a positive relationship between communication and students' employability.

Critical thinking is another soft skills that helps employee for career success. Critical thinking enables employee to work under stress, set priority and solve problem holistically (Tang, 2018). Critical thinking seems a very important soft skill for various types of organization. Though critical thinking is more associated with education, it is now also considered a major element of success at workplace (Zuo et al., 2018). When employees can think critically, then they can act more professionally. Professionalism helps in establishing boundaries at work, and showing respect to others (Hamilton \& Brabbit, 2007). Critical thinking also ensures work ethics, equity and fairness (Beeri et al., 2013). Critical thinking can accumulate information correctly that help people to take decision. Exercising critical thinking also helps one to conceptualize outcomes, solve complex problems and encourage on self-reflection. That is why employers prefer candidate with critical thinking skills. The following hypothesis is developed based on the above mentioned arguments.

H2: There is a positive relationship between critical thinking and students' employability.

Teamwork is an important ingredient of soft skills. Many studies have shown the effectiveness of teamwork in improving job performance (Kalleberg, 2009; Criss, 2010; Weinstein et al., 2013). Capacity in effective team building and working as team make people more empowered and connected. Rao (2017) has mentioned about teamwork for the 
employees that can achieve organizational goal more smoothly. Work ethics and morale are enhanced when people work in a team. It is also important to give joint effort for strategic business success. Teamwork generates higher productivity with positive work motivation (Tang, 2018). That is why employees need to have the ability to work in a team. During the employee selection process, teamwork skill is also investigated. Thus the next hypothesis of the study is

H3: There is a positive relationship between teamwork and students' employability.

\section{Conceptual Framework}

Based on the literature review, this study is proposing that communication, critical thinking and teamwork have the relationship with employability of graduates.

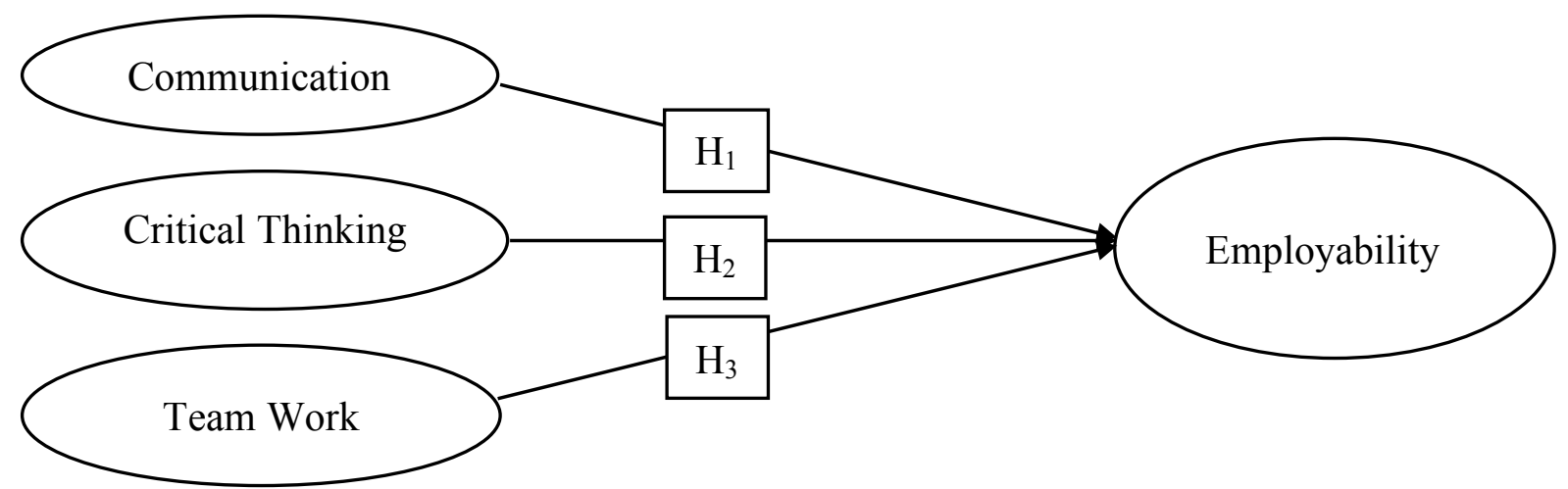

Figure 1. Conceptual Framework of the Study

\section{Research Design and Methodology}

A quantitative study has been done to find out the perceptions of students regarding the need of soft skills for getting job in Bangladesh. Specifically, this study has used Exploratory Factor Analysis (EFA), Confirmatory Factor Analysis (CFA) and the Structural Equation Modelling (SEM). Data of this study has been collected between January and February 2021 through structured questionnaire survey from 326 final year students from both public and private universities in Bangladesh. Total 10 (5 public and 5 private) universities across Bangladesh are selected purposively based on the convenience of the researcher. This study has adopted convenience sampling which is non-probability sampling subject to the convenient accessibility and proximity (Hair et al., 2010; Kothari, 2015). Questions are asked from different dimensions of soft skills that are required for graduate recruitments. The questionnaire of this study followed the dimensions used by Pritchard (2013) in his study on soft skills. Questionnaire has been designed in Google form and the link has been sent to the respondents though email and various social medias (Facebook Messenger, WhatsApp, IMO \& Viber). Data are then imported into SPSS file from MS Excel file. 
Table 1. Respondent Profile

\begin{tabular}{|c|c|l|c|c|}
\hline SL & \multicolumn{2}{|l|}{ Content } & Percentage & Frequency \\
\hline \multirow{2}{*}{$\mathbf{2}$} & \multirow{2}{*}{ Gender } & Male & 63.2 & 206 \\
\cline { 3 - 5 } & & Female & 36.8 & 120 \\
\hline \multirow{3}{*}{ Age } & Less than 20 years & 3.4 & 11 \\
\cline { 3 - 5 } & & 20-25 years & 72.7 & 237 \\
\cline { 3 - 5 } & & 25-35 years & 23 & 75 \\
\cline { 3 - 5 } & & $35-45$ years & .6 & 2 \\
\cline { 3 - 5 } & & 45 years or more & .1 & 1 \\
\hline \multirow{3}{*}{3} & \multirow{2}{*}{ Education } & Undergraduate & 60.7 & 198 \\
\cline { 3 - 5 } & & Graduate & 29.1 & 95 \\
\cline { 3 - 5 } & & Post Graduate & 10.1 & 33 \\
\hline
\end{tabular}

The respondents consisted of $63.2 \%$ male students and $36.8 \%$ are female. $60.7 \%$ respondents are undergraduate students whereas post-graduate students are only $10.1 \%$ and the remaining respondents have recently finished their bachelor degree but have not started job yet. Most of the respondents are young and their age is between 20 to 25 years. Meanwhile, to running the collected data from the respondent, twenty-one items are composed based on the theoretical framework. The twenty-one items stated are representing the most commonly perceived soft skills needed for getting a job, which are communication, critical thinking, teamwork and leadership.

Responses of twenty-one items have been analysed using Explanatory Factor Analysis (EFA) in SPSS 25 software. EFA is a useful tool for investigating the variable relationships for complex concepts (Hair et al., 2010). Before the final data analysis, normality test of collected data has been conducted through skewness and standard error (where, skewness/std.error $<1.96$ ). Only two items were not approved in normality test. Since the number is not significant, the data analysis can be carried out. However, homogeneity of the variance has been tested and box plot are drawn for data screening that are supported to do further data analysis.

First, a Principal Component Analysis (PCA) with rotation has been conducted to examine the factor structure of the 21 items, with multiple methods used to determine the number of factors underlying the data (e.g. eigenvalue-greater-than-one, screen plot, parallel analysis). Second, Structural Equation Modelling (SEM) has been conducted in order to see whether there were significant differences in the factors extracted from the PCA. SEM is a multivariate statistical analysis technique that is used to analyse structural relationships (Tabachnik \& Fidell, 2012). SEM technique is the combination of factor analysis (EFA \& CFA) and multiple regression (Hair et al., 2010), and it is used to analyse the structural relationship between measured variables and latent constructs. SEM method is preferred by the researcher since it estimates the multiple and interrelated dependence in a single analysis (Johnson \& Wichern, 2007).

In this analysis, two types of variables are used endogenous variables and exogenous variables. Endogenous variables are equivalent to dependent variables and are equal to the independent variable (Hair et al., 2010). SEM consists of measurement model and structural model (Hair et al., 2010). Measurement model is also known as path analysis which represents how measured variables come together to represent constructs (Tabachnik \& Fidell, 2012), and it is a set of relationships between exogenous and endogens variables. This is shown by the use of an arrow. The measurement model follows the assumption of unidimensionality. The structural model shows how constructs are related to each other as 
test of proposed casual relationships (Johnson \& Wichern, 2007). Therefore, this study has done an extensive study and analysis to confirm the factors and relationship between soft skills practice and employability as perceived by students.

\section{Reliability}

Reliability is defined as the extent to which a questionnaire, test, observation or any measurement procedure produces the same results on repeated trials (Kothari, 2015). It is evident that the reliability coefficient or alphas for the different constructs have been computed using the reliability procedure in SPSS. The reliabilities of all the constructs used in this study found to be above the standard set by Nunnally (1978), which is 0.89 .

\section{Data Analysis and Findings through EFA}

The principal component analysis with varimax rotation has been applied. Keiser-MeyerOlkin (KMO) score and Bartlett's test have been verified to know the adequacy of the data before factor analysis. Kaiser (1974) had suggested that for KMO in the 0.90s adequacy is marvellous, in the $0.80 \mathrm{~s}$ is meritorious, in the $0.70 \mathrm{~s}$ is middling, in the $0.60 \mathrm{~s}$ is mediocre, in the $0.50 \mathrm{~s}$ is miserable and below 0.5 - unacceptable. The Bartlett's test of sphericity should be significant (po0.05). Following phase of factor analysis is the choice of number of factors. The most popular criteria are: Kaiser rule - retain only those factors with an eigenvalue larger than 1; and Cattell criterion - a scree-plot. The extraction of factors is usually conducted by Principal Components Analysis (PCA). Principal component analysis is usually used in "typical" EFA - it is one of the techniques used for calculation of factor loadings. PCA is used as the adaptation of classical Hotteling's principle components analysis for factor analysis, and in practically is the most popular. The next step of factor analysis is the choice of rotation method. The goal of rotation is to simplify and clarify the data structure (Malina, 2004). On the basis of loadings values, it could indicate the variables with practically importance - it should be above \pm 0.5 . The analysis could be finished by interpretation of factors (using loading for all variables). Examination method of KMO that used to measure sampling adequacy suggested that the sample was factorable where about 0.919, and Bartlett's test of sphericity scored 2720.716 with significant level of 0.000 less than 0.05 , which means there are correlations between variables.

The communality, which means the amount of variance in each variable that can be explained by the factor model (Hair et al., 2010). This communality represents initial commonalities before rotation. It is the norm that the communality value for each variable must be above 0.5 to be accepted (Hair et al., 2010). Table 2 below illustrates each variable extraction value. For example, extraction value of variable X1 is 0.769 which mean that about $76.9 \%$ of variance can be explained by the form of X1 variable factors. Meanwhile, 0.732 is the amount of $\mathrm{X} 2$ variable extraction, which indicates that $73.2 \%$ of variance can be explained by the form of X2 variable factors.

Next stage for analysis, is the result of criteria analysis in the extraction factors which explained with Eigen value, cumulative percentage, scree plot, component matrix, and rotate component matrix. Eigen value explains the amount of variance in all the variables considered (Hair et al., 2010). There are four components with more than 1 eigenvalue, meaning that the number of factors formed are four. The cumulative percentage of total variance explained in this study is $66.15 \%$. Since this study is in social science where minimum value of cumulative percentage is $60 \%$, the formation of four factors have been considered as valid and acceptable. Scree plot shows that the line connected from the first 
four components have $>1$ eigenvalues. While the rest components, which are 5 to 21 , the eigenvalue is $<1$. This means that the factors that can be formed from 21 variables.

\begin{tabular}{|c|c|c|c|c|}
\hline & Table 2. & Rota & Component & rix $^{a}$ \\
\hline & & Con & ents & \\
\hline & $\begin{array}{l}\text { Communication } \\
\text { (Factor-I) }\end{array}$ & $\begin{array}{c}\text { Critical } \\
\text { Thinking } \\
\text { (Factor-II) }\end{array}$ & $\begin{array}{l}\text { Team Work } \\
\text { (Factor-III) }\end{array}$ & $\begin{array}{c}\text { Employability } \\
\text { (Factor-IV) }\end{array}$ \\
\hline $\mathrm{X} 1$ & 0.624 & & & \\
\hline $\mathrm{X} 2$ & 0.714 & & & \\
\hline $\mathrm{X} 4$ & 0.643 & & & \\
\hline $\mathrm{X} 5$ & 0.754 & & & \\
\hline $\mathrm{X} 7$ & 0.71 & & & \\
\hline X9 & 0.676 & & & \\
\hline $\mathrm{X} 18$ & & 0.578 & & \\
\hline X19 & & 0.71 & & \\
\hline $\mathrm{X} 20$ & & 0.813 & & \\
\hline $\mathrm{X} 21$ & & 0.709 & & \\
\hline $\mathrm{X} 10$ & & & 0.746 & \\
\hline $\mathrm{X} 12$ & & & 0.727 & \\
\hline $\mathrm{X} 13$ & & & 0.601 & \\
\hline X3 & & & & 0.625 \\
\hline $\mathrm{X} 14$ & & & & 0.654 \\
\hline $\mathrm{X} 15$ & & & & 0.606 \\
\hline Extra & tion Method: Prir & pal Compon & Analysis. & \\
\hline Rota & ion Method: Vari & x with Kais & ormalization. & \\
\hline
\end{tabular}

Table 2 shows rotated component matrix that helps to determine the components represent (Hair et al., 2010). This table shows that there is no cross loading of variables for the factors. Factor-I (Communication) consists of items X1, X2, X4, X5, X7 and X9. These five items represent communication as soft skill needed for getting job. Factor-II covers four items (X18, X19, X20 \& X21) and these refer critical thinking as another needed soft skills perceived by students for employability. Factor-III includes X10, X12 and X13 which represents team work. Factor-IV consists of X3, X14 \& X15 that refer employability.

Finding of the exploratory factor analysis in this study states that the students perceive three main soft skills as most important for getting job. These are communication, critical thinking, and team work. Communication skill help one individual to find out employment opportunity (Rao, 2015). Students with good communication skills can easily manage job since they are capable enough to convince the recruiter. One having communication skill can also understand the expected behaviour and requirement of employers. Critical thinking is another skill that recruiters look on job applicants. Critical thinking is tested in hiring the new employee since it comes up with innovative ideas, promote options and uncover the spinoffs (Zuo et al., 2018). Critical thinking ability also helps individual to be selected in the recruitment process. Teamwork increases work spirit and develops sense of belongingness (Johnson, 2016). Team work capacity of students are 
also essential as employee need to work in a team and this skill must be developed from the student life. To sum up as reflected in this study, communication, critical thinking and team work are mostly needed soft skills for student's employability in Bangladesh. To verify the findings of EFA, Confirmatory Factor Analysis (CFA) and Structural Equation Modelling (SEM) have been conducted in the next phase of the data analysis.

\section{Confirmatory Factor Analysis}

\section{Data Analysis and Findings}

Confirmatory Factor Analysis (CFA) was conducted to assess the construct validity of the model. Convergent validity is confirmation of the existence of a construct determined by the correlations exhibited by independent measures of the construct. To assess convergent validity, the loading estimates and construct reliability were investigated. In AMOS 21, convergent validity can be assessed and tested using the measurement model by determining the significant t-value of each item's estimated pattern coefficient on its posited underlying construct factor (Anderson \& Gerbing, 1988). CFA was performed using AMOS 21. A good rule of thumb is that standardized loading estimates should be $>0.5$ (Hair et al., 2010). Based on the Figure 2, it can be seen that communication (COM); critical thinking (CT) and teamwork (TW) have factor loading more than 0.5 . The CFA results provide overall fit indices $\left(\mathrm{X}^{2}=254.644\right)$, chi-square degree of freedom (Normed chi-square) $=2.274$, root mean square error of approximation $(\mathrm{RMSEA})=0.063$. Figure 2 shows the model fit results.

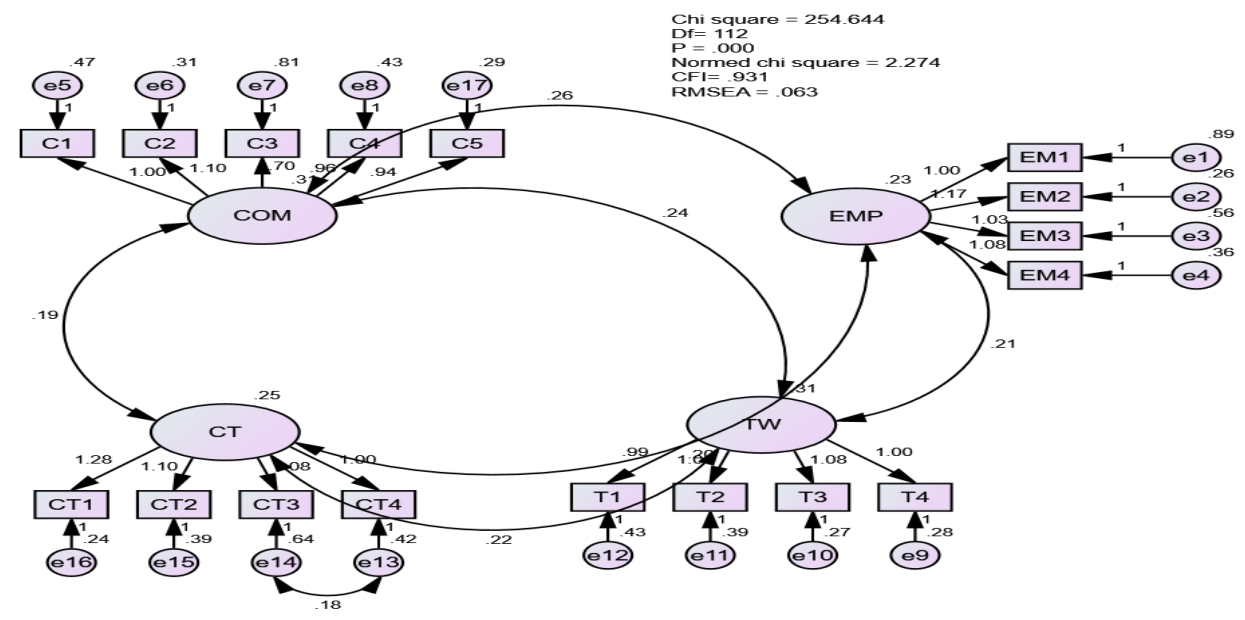

Figure 2. Confirmatory Factor Analysis

As it can be seen from Figure 2, Normed chi-square $=2.274$ is a good fit, because it should be range from as high as 5.0 (Wheaton et al., 1977) to as low as 2.0 (Tabachnick \& Fidell, 2012). CFI $=0.931$ is a good fit. A rule of thumb for the CFI and the incremental indexes is that values above 0.90 may indicate reasonably good fit (Hair et al., 2010) of the researcher's model. Next, RMSEA $=0.063$ is good fit. Hair et al., (2010) suggested $0.03<$ RMSEA < 0.08 is for "good fit". Therefore, confirmatory factor analysis for the final measurement model reasonably supported the model's fit.

\section{Structural Equation Modelling (SEM)}

SEM has been used to test the hypothesized proposed. SEM technique enables the simultaneous estimation of multiple regression equations in a single framework (Hair et al., 2010). The model was estimated using maximum likelihood method. A structural model is 
fit to communication, critical thinking, teamwork and employability presented in figure 3 . The goodness of fit indices for the final structural model suggested a good fit to the data: small ratio of normed chi-square $(2<$ normed chi-square $<5)$ (Wheaton et al,. 1977; Tabachnik \& Fidell, 2012), great values of CFI $(>0.9)$ and RMSEA values $(0.03<$ RMSEA $<0.08$ ) (Hair et al., 2010).

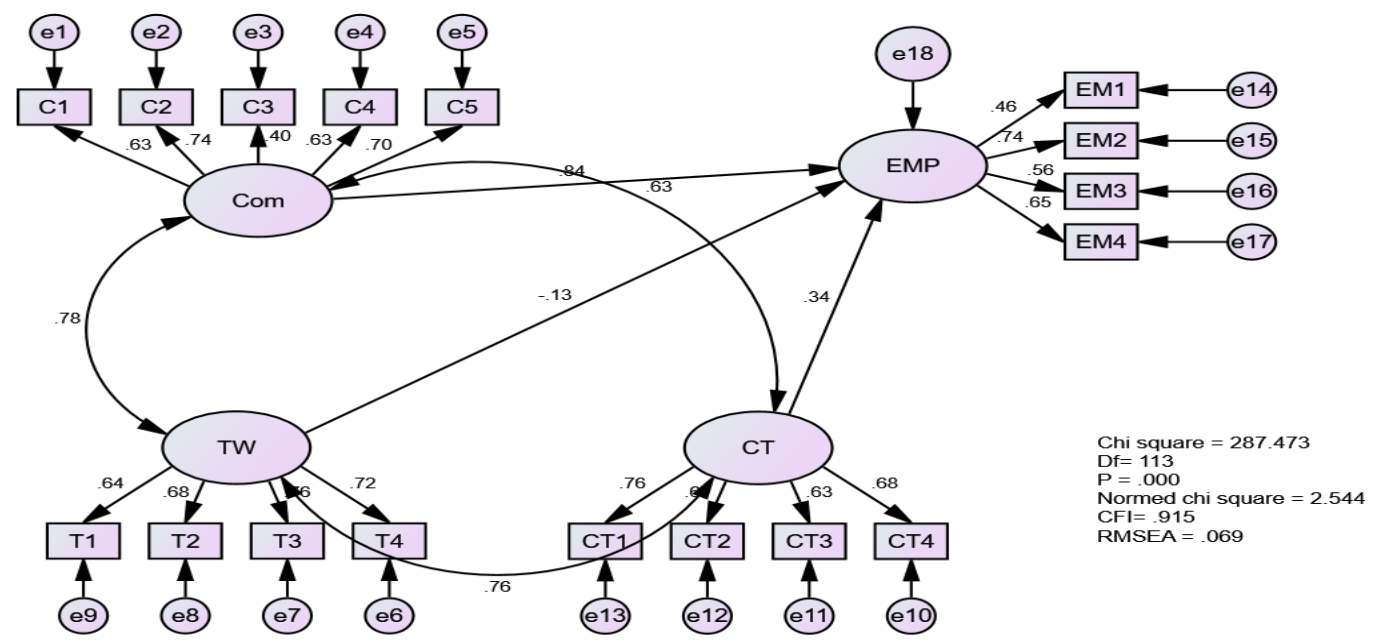

Figure 3. Structural Equation Modelling (SEM)

\section{Hypotheses Test}

The hypotheses testing results are displayed in Table 3. As shown in Table 3, the p-value of communication to employability is 0.008 , which is less than 0.05 . It can be concluded that H1 is supported, meaning that communication has a significant effect on employability. Next, $p$-value of critical thinking to employability is 0.006 , which is less than 0.05 . It can be concluded that $\mathrm{H} 2$ is accepted, meaning that critical thinking has significant effect on employability. Finally, $p$-value of team work to employability is 0.001 , which is less than 0.05 . It can be concluded that $\mathrm{H} 3$ is supported, meaning that team work has a significant effect on employability.

Table 3. Hypotheses Testing Result

\begin{tabular}{cccc} 
Path & Beta & p-value & Result \\
\hline Com $\rightarrow$ EMP & 0.63 & 0.008 & Supported \\
\hline $\mathrm{CT} \rightarrow$ EMP & 0.34 & 0.006 & Supported \\
\hline $\mathrm{TW} \rightarrow$ EMP & 0.13 & 0.001 & Supported \\
\hline
\end{tabular}

\section{Discussion}

Finding of the EFA states that the students perceive three soft skills as most important for getting job. These are communication, critical thinking and teamwork. These three softs skills have also supported the model's fit in CFA for the measurement model. Through SEM, the significant relationships among communication, critical thinking, teamwork and employability are found. First of all, communication skill helps one individual to find out employment opportunity (Rao, 2015). Students with good communication skills can easily manage job since they are capable enough to convince the recruiter. One having communication skill can also understand the expected behaviour and requirement of 
employers. Thus, it is rational that $\mathrm{H} 1$ is accepted. Secondly, critical thinking is a soft skill that recruiters look from job applicants. Critical thinking is tested in hiring the new employee since it comes up with innovative ideas, promote options and uncover the spinoffs (Zuo et al., 2018). Critical thinking ability also helps individual to be selected in the recruitment process. That is why students perceive critical thinking as required soft skills for employability based on which $\mathrm{H} 2$ is tested as accepted. Finally, teamwork increases work spirit and develops sense of belongingness (Johnson, 2016). Team work capacity of students are also essential as employee need to work in a team and this skill must be developed from the student life. Therefore, H3 is accepted. To sum up as reflected in this study, communication, critical thinking and teamwork are mostly needed soft skills for student's employability in Bangladesh.

\section{Conclusion and Implications}

Soft skills are positive attributes that help one to stay focused, connected and self-driven. Soft skills are equally essential both in personal and work life. Employee can perform better when their communication skills are appropriate. Critical thinking ability makes individual strategic and target oriented. Teamwork brings best output from the group effort. That is why these three are perceived by the students to develop as employers look for these skills while hiring new employees. This study has mentioned the significance of developing communication, critical thinking and teamwork for getting job at early career. It also identifies the positive relationships among these three with employability.

This study has several implications. Findings of the study will be useful for the stakeholders to be more concerned on employment crisis. As the main cause of unemployment for graduates is the absence of industry-academia collaboration, this study will draw the attention of educational institutes, policy makers and students to emphasis more specifically on developing soft skills for career opportunity and professional development. Besides, this study has used Social Exchange Theory (SET) to understand the counterpart result of acquiring soft skills and getting employment benefits in return, which is a new contribution into the field of management.

\section{Limitation and Recommendations for Future Research}

This study is limited to the soft skills acquisition by students and employability. Further study can be done to know the relationship between soft skills practice and other Human Resource Management (HRM) areas such as job performance, job satisfaction, employee commitment etc. EFA, CFA and SEM have been done in this study to test the direct relationships among the variables. But further extension of the study can be done through mediation and moderation effects in SEM. Since, the students' perception is only considered in this study, there is a scope for future research to conduct study by integrating the responses from employers, experts and graduates to know the role of soft skills for employability.

\section{References}

Alam.M, A. Gale, Brown, M. \& Khan, A. (2010). The importance of human skills in project management professional development. International Journal of Managing Projects in Business, 3(3), 495-516, https://doi.org/10.1108/17538371011056101

Anderson, J. C. and Gerbing, D.W. (1988). Structural Equation Modeling in Practice: A Review and Recommended Two Step Approach. Psychological Bulletin, 103: 411423. 
Andreas, B. \& Hiroshi, S. (2011). Employability and Skill Set of Newly Graduated Engineers in India. World Bank Policy Research Paper, 6540.

Azami, Z., Yuzainee, M. Y., Zaidi, O., Azah, M., Norhamidi, M. \& Ramli, M. (2009). Employers Perception towards Engineering Employability Skills in Asia. Wseas Transactions on Advances in Engineering Education, 306-310.

Beeri, I, Dayan, R. Gadot, E. \& Werner, S. B. (2013). Advancing Ethics in Public Organizations. Journal of Business Ethics, 112(1), 59-78.

Criss, Ellen (2010). Teamwork in the Music Room. Music Educators Journal, 97 (1), 30-36.

Cross, C., \& Dundon, T. (2019). Social exchange theory, employment relations and human resource management. In Elgar Introduction to Theories of Human Resources and Employment Relations. UK: Edward Elgar Publishing.

Emerson, R. M. (1976). Social Exchange Theory. Annual Review of Sociology, 2 (1976), 335-362.

Fong, L. L., Sidhu. G.K., \& Fook, C.Y. (2014). Exploring 21st Century Skills among Postgraduates in Malaysia. Procedia - Social and Behavioral Sciences, 123, 130-138. doi:10.1016/j.sbspro.2014.01.1406

Gibb, S. (2014). Soft skills assessment: theory development and the research agenda. International Journal of Lifelong Education, 33(4), 455-471. http://doi.org/10.1080/02601370.2013.867546

Hair, J.F., Black, W.C., Babin, B.J. \& Anderson, R.E. (2010). Multivariate Data Analysis. 7th Edition. New York: Pearson.

Hamilton, N \& Brabbit, L. M. (2007). Fostering Professionalism through Mentoring. Journal of Legal Education, 57(1), 102-129.

Hossan, C.G., Sarker, A. R. \& Afroze, R. (2012). An assessment of managerial skills in the labour intensive industry: A case study of a garments manufacturing firm. Journal of Accounting, Business and Management, 19(2): 1-14.

Islam, M A., \& Saif, A, N, M. (2020) Graduate employability matters more than ever. Available at: https://www.thedailystar.net/business/news/graduate-employabilitymatters-more-ever-1930085

Johnson, K. M. (2016). Non-Technical Skills for IT Professionals in the landscape of Social Media. American Journal of Business and Management, 4(3), 102-122. http://doi.org/10.11634/216796061504668

Johnson, R.A., \& Wichern, D.W. (2007). Applied Multivariate Statistical Analysis, 7/e. New Jersey: Prentice Hall.

Kaiser, H.F. (1974). An Index of Factorial Simplicity. Psychometrika. 39 (1), 31-36.

Kalleberg, A., Nesheim, T. \& Olsen, K. (2009). Is Participation Good or Bad for Workers? Effects of Autonomy, Consultation and Teamwork on Stress Among Workers in Norway. Acta Sociologica, 52 (2), 99-116.

Kechagias, K. (2011). Teaching and assessing soft skills, MASS Project report. School of Thessaloniki, Neapoli.

Khata, Y. M. Sukri M, Syed SMS, Haszlinna, N. (2013). Employability Skills Element's: Difference Perspective between Teaching Staff and Employers Industrial in Malaysia. Procedia - Social and Behavioral Sciences, 93, 1531-1535. doi :10.1016/j.sbspro.2013.10.077

Kothari, C. (2015). Research Methodology: Methods and Techniques. $2^{\text {nd }}$ edition. New Delhi: New Age International Publication Ltd.

Majid, S., Liming, Z., Tong, S., \& Raihana, S. (2012). Importance of Soft Skills for Education and Career Success. International Journal for Cross-Disciplinary Subjects 
in Education, 2(Special 2), 1036-

1042.http://doi.org/10.20533/ijcdse.2042.6364.2012.0147

Malina, A. (2004). The Factor Analysis in Research of the Spatial Differentiation of Poland's Economic Structure. Statistics in Transition. 6 (7)

Mason, G., Williams, G., \& Crammer, S. (2006). Employability skills initiatives in Higher Education: What effects do they have on graduate labour market outcomes? London: National Institute of Economic and Social Research and Institute of Education.

Naim, M. (2017). Soft Skill Development: Relevance of Neuro-Linguistic Programming (NLP). Language in India, 17(2), 160-176.

Nazir, S., Qun, W., Hui, L., \& Shafi, A. (2018). Influence of social exchange relationships on affective commitment and innovative behavior: Role of perceived organizational support. Sustainability, 10(12), 4418.

Nunnally, J. C. (1978). Psychometric Theory. New York: McGraw-Hill.

Patacsil, F. \& Tablatin, C. S. (2017). Exploring the Importance of Soft and Hard Skills As Perceived By It Internship Students and Industry: a Gap Analysis. Journal of Technology and Science Education, 7(3), 347-368. http://doi.org/10.3926/jotse.271

Pritchard, J., 2013. The importance of soft skills in entry-level employment and postsecondary success: Perspectives from employers and community colleges. Seattle, WA: Seattle Jobs Initiative.

Rao, M.S. (2015). Step by step to soft-skills training: How to enhance employability skills in students. Human Resource Management International Digest, 23(6), 34-36.

Rao, M.S. (2017). Innovative tools and techniques to ensure effective employee engagement. Industrial and Commercial Training, 49(3), 127-131. https://doi.org/10.1108/ICT06-2016-0037

Roos, S. J., Lennox, A., \& Botha-Ravyse, C. (2016). Student'S Soft Skill Acquisition in an Outdoor Adventure Education Event Over Two Years of Participation. International Journal of Social Sciences and Humanity Studies, 8(2), 1309-8063.

Sattar, M., Yusof, M., Napsiah, Rashid, M. and Amnah, R. (2009) Peranan= Institusi Pendidikan Teknikaldalam Pemupukan Kemahiran "Employability' Pelajar Jurnal Teknologi 50(50 (E)), 113-127.

Shafie, L., \& Nayan, S. (2010). Employability awareness among Malaysian undergraduates. International Journal of Business \& Management, 5(8), 119-123.

Smith, J., (2015). Business Research Methodology. New York: Arclepress.

Szilárd, S., Benedek, A., \& Ionel-Cioca, L. (2018). Soft Skills Development Needs and Methods in Micro-Companies of ICT Sector. Procedia - Social and Behavioural Sciences, 238, 94-103. https://doi.org/10.1016/j.sbspro.2018.03.012

Tabachnick, B.G. and Fidell, L.S. (2012). Using Multivariate Statistics. 6th Edition. New York: Allyn and Bacon.

Tang, K. N. (2018). The importance of soft skills acquisition by teachers in higher education institutions. Kasetsart Journal of Social Sciences, 2-7.

Taylor, E., (2016). Investigating the perception of stakeholders on soft skills development of students: Evidence from South Africa. Interdisciplinary Journal of E-Skills and Lifelong Learning, 12(1): 1-18.

Waskito, J., Riani, A. L., Suyono, J., \& Setiawan, A. I. (2020). Does the Social Exchange Theory (SET) Work Effectively for New Employees? An Empirical Study of Contingent Worker in Indonesia. Pertanika Journal of Social Sciences \& Humanities, 28(2). 
Weinstein, J., Morton, L., Taras, H. \& Reznik, V. (2013). Teaching Teamwork to Law Students. Journal of Legal Education, 63 (1), 36-64.

Wesley, S. C., Jackson, V. P., \& Lee, M. (2017). The perceived importance of core soft skills between retailing and tourism management students, faculty and businesses. Employee Relations, 39(1), 79-99. https://doi.org/10.1108/ER-03-2016-0051

Wheaton, B., et al. (1977). Assessing Reliability and Stability in Panel Models. Sociological Methodology. 8 (1), 84-136.

Yeardley, T. (2017). Training of new managers: why are we kidding ourselves? Industrial and Commercial Training, 49(5), 245-255, ISSN 0019-7858, doi: 10.1108/ICT-122016-0082.

Zaman, L., Sarker,A.R, and Akhter, N. (2018). Study on Practice of Soft Skill among the Workforce: A Case from Ready Made Garment (RMG) Industry of Bangladesh. International Journal of Asian Social Science, 8(10),808-8018, ISSN: 2226-5139.

Zuo, J., Zhao, X., Nguyen, Q. B. M., Ma, T., \& Gao, S. (2018). Soft skills of construction project management professionals and project success factors: A structural equation model. Engineering, Construction and Architectural Management, 25(3), 425-442. https://doi.org/10.1108/ECAM-01-2016-0016 